\title{
The association between admission blood urea nitrogen levels with in-hospital and long-term mortality in ST-segment elevation myocardial infarction
}

\author{
ST-segment elevasyonlu milyokard infarktüsüinde \\ başvuru kan üre azotu ile hastane içi ve uzun dönem \\ mortalite arasındaki ilişki
}

Mustafa Adem Tatlısu', Adnan Kaya ${ }^{2}$, Muhammed Keskin², Ömer Kozan ${ }^{3}$

${ }^{1}$ Department of Cardiology, Istanbul Medeniyet University Faculty of Medicine, Istanbul, 34000, Turkey

${ }^{2}$ Department of Cardiology, Duzce University Faculty of Medicine, Duzce, 81620, Turkey

${ }^{3}$ Department of Cardiology, Dr. Siyami Ersek Cardiovascular Surgery Research and Training Hospital, Istanbul, 34773 , Turkey

Corresponding author:H Mustafa Adem Tatlisu, MD., Department of Cardiology, Istanbul Medeniyet University Faculty of Medicine, Istanbul,

34000, Turkey

E-mail: ademtatlisu@gmail.com

Received/Accepted:April 25,2018/September 28, 2018

Conflict of interest: There is not a conflict of interest.

\section{SUMMARY}

Objective: The aim of this study was to investigate the association of blood urine nitrogen (BUN) levels with all-cause mortality in ST-segment elevation myocardial infarction (STEMI).

Method: This study included 3778 patients with STEMI treated with primary percutaneous coronary intervention. An admission BUN of $17.5 \mathrm{mg} / \mathrm{dL}$ was identified through a ROC analysis as an optimal cutoff value to predict the inhospital mortality with 68\% sensitivity and 66\% specificity (AUC: $0.75 ; 95 \%$ CI:0.72-0.88; p $<0.001$ ).

Results: The patients were followed up for a mean period of $33 \pm 0.14$ months. Patients with higher BUN levels had 5.3times higher in-hospital (OR: 6.0, 95\% CI: 4.4-8.3) and 5-times higher long-term (HR: 5.3, 95\% CI: 4.2-6.8) mortality rates than patients with lower BUN levels.

Conclusions: This study demonstrated that elevated BUN level was independently associated with increased in-hospital and long-term mortality. BUN test is a simple, inexpensive, and easily bedside applicable method. Hence, it can be used to detect high-risk patients in the setting of STEMI.

Keywords: Blood urine nitrogen; ST-segment elevation myocardial infarction; primary percutaneous coronary intervention; mortality

\section{ÖZET}

Amaç: Çalışmanın amacı kan üre azotu (KÜA) seviyesi ile ST-elevasyonlu miyokard infarktüsündeki (STEMI) tüm nedenli mortalite arasındaki ilişkiyi araştırmaktı.

Yöntem: Bu çalışma primer perkütan koroner girişim yapılan 3378 STEMI hastalarını içermekteydi. Hastane içi mortalitede bașvuru KÜA seviyesi eșik değeri ROC analizinde $17.5 \mathrm{mg} / \mathrm{dL}$ olarak ve sensivite \%68, spesifite $\% 66$ olarak saptanmıştır (AUC: 0.75; 95\% CI:0.72-0.88; p < 0.001). 
Bulgular: Hastalar ortalama olarak $33 \pm 0.14$ ay izlenmiștir. Yüksek KÜA seviyesine sahip hastalarda düşük KÜA seviyesine sahip hastalara göre hastane içi mortalite 5.3 kat (OR: 6.0, 95\% CI: 4.4-8.3), uzun dönem mortalite 5 kat (HR: 5.3, 95\% CI: 4.2-6.8) yüksek olarak saptanmıştır.

Sonuç: Bu çalışmada yüksek KÜA seviyesi bağımsız olarak hastane içi ve uzun dönem mortalite ile ilişkili olarak bulunmuştur. KÜA testi basit, ucuz ve kolaylıkla uygulanabilen bir yöntemdir. Bu yüzden, STEMİ geçiren yüksek riskli hastaları saptamada kullanılabilir.

Anahtar sözcükler: Kan üre azotu, ST-elevasyonlu miyokard infarktüsü, primer perkütan koroner girişim

\section{INTRODUCTION}

Risk stratification of patients with acute coronary syndrome (ACS), which is the leading cause of death worldwide $^{1}$, is so important in order to initiate appropriate medical treatment. There are several parameters used for prediction of mortality in $\mathrm{ACS}^{2-7}$. An increase in serum creatinine $(\mathrm{sCr})$ levels has been found as a predictor of adverse events and mortality in $\mathrm{ACS}^{7-11}$. Despite the fact that blood urea nitrogen (BUN) is another commonly used parameter to evaluate kidney function in routine clinical practice, the impact of increased BUN levels on mortality in ACS has not been well established yet. The aim of this study was to investigate the association of BUN levels with all-cause mortality and major cardiac events (MACE) in ST-segment elevation myocardial infarction (STEMI) patients treated with primary percutaneous coronary intervention (pPCI).

\section{MATERIAL AND METHODS}

\section{Study participants}

This retrospective study included 3844 consecutive patients with STEMI undergoing pPCI from January 2008 to December 2011 at the tertiary research hospital of a high volume center (1194 pPCI and 2032 elective PCI were performed by 25 interventional cardiologists in 2010). The only exclusion criterion was current renal replacement therapy. A total of 26 patients were excluded because of having at least one of the exclusion criteria. An additional 12 patients were excluded from the study due to the fact that BUN measurements were not performed at admission. An additional 28 patients were excluded from the study due to loss to follow-up. All follow-up data were obtained from hospital medical records or by interviewing (directly or by telephone) patients, their families, or their personal physicians. The study was terminated after a follow-up period of 36 months. The study was approved by the Institutional Ethics Committee.

\section{Analysis of patient data}

A clinical history of risk factors, such as age, gender, hypertension, diabetes mellitus, hyperlipidemia, renal insufficiency was determined from the hospital's medical database. Echocardiographic and coronary angiographic findings were also obtained from the same database. An echocardiogram was performed in $93 \%$ patients at first 48 hours in the coronary care unit and left ventricular ejection fraction (LVEF) was calculated by using Simpson method ${ }^{12}$. Nonionic low osmolality contrast media was used in all patients $(616 \mathrm{mosmol} / \mathrm{kg})$. The occurrences of in-hospital and long-term events were evaluated by a trained study coordinator. Following coronary angiography or pPCI, the patients were admitted to coronary care unit for follow-up monitorization. The estimated glomerular filtration rate (eGFR) was calculated by using Cockcroft-Gault equation ${ }^{13}$. The drugs were administered during and after the hospitalization according to the European Society of Cardiology Guidelines ${ }^{14}$. Acute kidney injury is defined as an increase in serum creatinine level of $\geq 0.5 \mathrm{mg} / \mathrm{dL}$ or a relative $25 \%$ increase from baseline creatinine value, assessed at 48 hours after the angiography ${ }^{15}$. Blood values obtained from venous blood samples at hospital admission were recorded from the medical reports. White blood cell, hemoglobin level, and platelet counts were measured as a part of the automated complete blood count using a Coulter LH 780 Hematology Analyzer (Beckman Coulter Ireland, Inc, Galway, Ireland). Biochemical measurements were performed using Siemens Healthcare Diagnostic Products kits and calibrators (Marburg, Germany). Creatine kinase isoenzyme-MB (CK-MB) levels were measured using an immune-inhibition method (Architect C 8000; Abbott Inc).

\section{Angiographic analysis}

All patients underwent pPCI within 60 minutes of admission. All pPCI procedures were performed 
using the standard femoral approach with a 6-Fr guiding catheter. Medication before the pPCI included $600 \mathrm{mg}$ of clopidogrel and $300 \mathrm{mg}$ of chewable aspirin. Direct stenting was performed whenever possible; in the remaining cases, balloon predilatation was performed. The drugeluting stent was used whenever possible. To achieve maximal dilation, an intracoronary injection of nitroglycerin $(100 \mu \mathrm{g})$ was administered in each coronary angiogram. All patients were treated with maintenance doses of clopidogrel (75 mg once daily for 12 months) and aspirin (100 mg indefinitely).

\section{Endpoints}

The primary endpoints were the incidence of inhospital and long-term all-cause mortality. The secondary endpoint was MACE, which includes all-cause death, non-fatal acute coronary syndrome (ACS), and target lesion revascularization (TLR). Evaluation of MACE was obtained from hospital's medical database or by follow-up interviews (directly or by telephone).

\section{Definition of short-term and long-term events}

TLR was defined as vascularization of the stented segment or within 5-mm margins proximal or distal to the stent by either repeat PCI or coronary artery bypass grafting. Non-fatal ACS was described as a 2-fold increase in serum CK-MB enzyme levels and/or ST segment re-elevations. Stent thrombosis and in-hospital ventricular arrhythmias were also analyzed. Stent thrombosis was defined as an abrupt onset of cardiac symptoms along with an elevation in levels of biomarkers or electrocardiographic evidence of myocardial injury after stent deployment in the first $24 \mathrm{~h}$. This was accompanied by angiographic evidence of a flow-limiting thrombus near a previously placed coronary stent.

\section{Statistical analysis}

In a first step, an admission BUN of $17.5 \mathrm{mg} / \mathrm{dL}$ was identified through a ROC analysis as an optimal cutoff value to predict the in-hospital mortality. Two groups were formed accordingly: one with 2328 patients $(\mathrm{BUN}<17.5)$ and the other with 1450 patients (BUN $\geq 17.5)$. In a second step, baseline characteristics were compared between two groups. Kolmogorov-Smirnov test was used for testing of normality. All continuous variables showed skewed distributions and expressed as median and, 25th and 75th percentiles; and compared using the Kruskal-Wallis test. Categorical variables were expressed as number and percentages, and Pearson's chi-square or
Fisher's exact tests were used to evaluate the differences. In a third step, to analyze the prediction for in-hospital mortality, data from the admission parameters were employed as independent variables. The univariate relationship between baseline characteristics and in-hospital mortality were assessed by univariate hierarchical logistic regression analysis. Multivariate analysis by stepwise logistic regression models (backward elimination) tested variables that were significant at $\mathrm{p}<0.1$ in the univariate analysis. In a fourth step, after a mean follow-up period of $33 \pm 0.14$ months, the median survival times (MST) of two groups were compared using the Kaplan-Meier survival method. Overall survival was calculated from the day of diagnosis to the day of death or last follow-up. Differences between the groups were analyzed by the log-rank test. A forward Cox proportional regression model was used for multivariable analysis. The univariate relationship between baseline characteristics and long-term mortality were assessed by univariate Cox regression analysis. Multivariate analysis by stepwise Cox regression models (backward elimination) tested variables that were significant at $\mathrm{p}<0.1$ in the univariate analysis. A two-tailed $\mathrm{p}$ value of $<0.05$ was considered as statistically significant, and $95 \%$ CIs were presented for all odds ratios and hazard ratios. Analyses were performed using Statistical Package for Social Sciences software, version 16.0 (SPSS; IBM, Armonk, New York, USA).

\section{RESULTS}

A total of 3778 patients (mean age $58.3 \pm 11.8$ years; men $81 \%$ ) with STEMI were included. The patients' baseline characteristics, categorized by admission BUN, are listed in Table 1. There was a significant difference in terms of age $(p<0.001)$ and gender $(\mathrm{p}<0.001)$ among the subgroups of BUN. The history of patients was similar in terms of hyperlipidemia $(\mathrm{p}=0.632)$, current smoking status $(\mathrm{p}=0.280)$ and previous PCI $(\mathrm{p}=0.375)$. Whereas, the history of patients was significantly different in terms of hypertension $(p<0.001)$, diabetes mellitus $(\mathrm{p}<0.001)$, previous MI $(\mathrm{p}=0.009)$, previous CABG $(\mathrm{p}=0.003)$, and chronic kidney disease $(\mathrm{p}<0.001)$. At admission, the groups were similar in terms of systolic blood pressure $(\mathrm{p}=0.069)$, diastolic blood pressure $(p=0.921)$, heart rate $(p=0.254)$, Killip class $(p=0.243), \quad$ LVEF $\quad(p=0.076), \quad$ and anterior myocardial infarction incidence $(\mathrm{p}=0.161)$. Patients' chest-pain-period and door-to-balloon- 
time were similar $(\mathrm{p}=0.383$ and $\mathrm{p}=0.103$ respectively).

The patients' laboratory parameters are summarized in Table 1 . In laboratory parameters, the patients showed significant differences by the respect of admission creatinine $(p<0.001)$ and eGFR $(\mathrm{p}<0.001)$. Whereas; the groups were similar with respect to $\mathrm{CK}-\mathrm{MB}(\mathrm{p}=0.060)$, peak CK-MB ( $\mathrm{p}=0.083)$, white blood cell count $(\mathrm{p}=0.214)$, hematocrit $(\mathrm{p}=0.159)$ and platelet count $(\mathrm{p}=0.195)$. The patients' coronary angiographic parameters are summarized in Table 1. The patients with higher BUN levels had significantly higher 3 -vessels disease $(p<0.001)$. The type of PCI and stent were similar between the groups. Generally, TIMI flow grades between the groups were similar before the intervention. However, patients with higher BUN levels had significantly lower TIMI III flow grade ratios after intervention compared to patients with lower BUN levels.

Table 1. Baseline characteristics of patients stratified by admission blood urea nitrogen level

\begin{tabular}{|c|c|c|c|}
\hline & \multicolumn{2}{|c|}{ Blood Urea Nitrogen Level (mg/dL) } & \multirow[b]{2}{*}{$\begin{array}{c}\mathrm{P} \\
\text { Value }\end{array}$} \\
\hline & $\begin{array}{c}<17.5 \mathrm{mg} / \mathrm{dL} \\
(\mathrm{n}=2328)\end{array}$ & $\begin{array}{c}\geq 17.5 \mathrm{mg} / \mathrm{dL} \\
(\mathrm{n}=1450)\end{array}$ & \\
\hline Age & $55.0(48.0-62.0)$ & $63(55.0-71.0)$ & $<0.001$ \\
\hline Male gender & $1951(83.8)$ & $1118(78.7)$ & $<0.001$ \\
\hline Body mass index & $134(120-156)$ & $133(118-156)$ & 0.193 \\
\hline \multicolumn{4}{|l|}{ History } \\
\hline Hypertension & $205(21.5)$ & $456(32.1)$ & $<0.001$ \\
\hline Diabetes mellitus & $455(19.7)$ & $354(25.1)$ & $<0.001$ \\
\hline Hyperlipidemia & $535(23)$ & $336(23.7)$ & 0.632 \\
\hline Current smoking status & $650(27.9)$ & $420(29.6)$ & 0.280 \\
\hline Previous MI & $482(20.7)$ & $347(24.4)$ & 0.009 \\
\hline Previous PCI & $451(19.4)$ & $292(20.6)$ & 0.375 \\
\hline Previous CABG & $95(4.1)$ & $89(6.3)$ & 0.003 \\
\hline Chronic kidney disease & $58(2.5)$ & $173(12.2)$ & $<0.001$ \\
\hline \multicolumn{4}{|l|}{ At admission } \\
\hline Systolic blood pressure (mm Hg) & $134(120-156)$ & $133(118-156)$ & 0.069 \\
\hline Diastolic blood pressure $(\mathrm{mm} \mathrm{Hg})$ & $70(64-79)$ & $70(64-81)$ & 0.921 \\
\hline Heart rate (beats per minute) & $78(70-85)$ & $78(69-88)$ & 0.254 \\
\hline Killip classification & $2.0(1.0-2.5)$ & $2(1.0-2.5)$ & 0.243 \\
\hline Left ventricular ejection fraction (\%) & $50(45-60)$ & $50(45-55)$ & 0.076 \\
\hline Anterior myocardial infarction & $944(40.5)$ & $609(42.9)$ & 0.161 \\
\hline Chest pain period (hours) & $6.0(2.0-12.0)$ & $6.0(2.0-12.0)$ & 0.383 \\
\hline Pain-to-balloon time (hours) & $6.2(2.4-12.2)$ & $6.2(2.3-12.1)$ & 0.347 \\
\hline Door-to-balloon time (minutes) & $28(22-31)$ & $26(18-30)$ & 0.103 \\
\hline \multicolumn{4}{|l|}{ Admission laboratory variables } \\
\hline Admission CK-MB (ng/mL) & $48(23-118)$ & $50(25-123)$ & 0.060 \\
\hline Peak creatine kinase-MB $(\mathrm{ng} / \mathrm{mL})$ & $101(40-197)$ & $103(45-214)$ & 0.083 \\
\hline Creatinine $(\mathrm{mg} / \mathrm{dL})$ & $0.8(0.7-0.9)$ & $1.0(0.8-1.2)$ & $<0.001$ \\
\hline eGFR $\left(\mathrm{ml} / \mathrm{min} / 1.73 \mathrm{~m}^{2}\right)$ & $121(112-146)$ & $89(81-126)$ & $<0.001$ \\
\hline White blood cell count, cells $/ \mu \mathrm{L}$ & $11.0(9.0-13.6)$ & $11.2(8.9-14.0)$ & 0.214 \\
\hline Hematocrit, \% & $41.0(38.0-44.0)$ & $40.0(36.0-43.0)$ & 0.159 \\
\hline Platelet count, cells $/ \mu \mathrm{L}$ & $235(200-280)$ & $232(192-277)$ & 0.061 \\
\hline Blood urea nitrogen $(\mathrm{mg} / \mathrm{dL})$ & $13(7-16)$ & $23(19-27)$ & $<0.001$ \\
\hline \multicolumn{4}{|l|}{ Vessel disease (stenosis $>50 \%$ ) } \\
\hline 1 vessel & $1401(60.2)$ & $739(52.0)$ & $<0.001$ \\
\hline 2 vessels & $541(23.2)$ & $368(25.9)$ & 0.064 \\
\hline 3 vessels & $386(16.6)$ & $312(22.0)$ & $<0.001$ \\
\hline \multicolumn{4}{|l|}{ PCI type } \\
\hline Only PTCA & $337(14.5)$ & $222(15.6)$ & 0.334 \\
\hline Only Stent & $342(14.7)$ & $180(12.7)$ & 0.084 \\
\hline PTCA and Stent & $1346(57.8)$ & $809(57.0)$ & 0.634 \\
\hline \multicolumn{4}{|l|}{ Stent type } \\
\hline Drug eluting stent & $1442(61.9)$ & $842(59.3)$ & 0.115 \\
\hline Bare metal stent & $246(10.6)$ & $147(10.4)$ & 0.869 \\
\hline \multicolumn{4}{|l|}{ TIMI flow grade before intervention } \\
\hline TIMI 0 & $1522(65.4)$ & $915(64.4)$ & 0.572 \\
\hline TIMI I & $230(9.9)$ & $143(10.1)$ & 0.850 \\
\hline TIMI II & $206(8.8)$ & $138(9.7)$ & 0.371 \\
\hline TIMI III & $574(24.7)$ & $402(28.3)$ & 0.013 \\
\hline \multicolumn{4}{|l|}{ TIMI flow grade after intervention } \\
\hline TIMI 0 & $132(5.7)$ & $106(7.5)$ & 0.029 \\
\hline TIMI I & $153(6.6)$ & $170(12.0)$ & $<0.001$ \\
\hline TIMI II & $229(9.8)$ & $141(9.9)$ & 0.926 \\
\hline TIMI III & $1821(78.2)$ & $1008(71.0)$ & $<0.001$ \\
\hline
\end{tabular}




\begin{tabular}{lcc}
\hline $\begin{array}{l}\text { Discharge medication } \\
\text { B-blocker }\end{array}$ & $2044(87.8)$ & $1248(87.9)$ \\
\hline Statin & $821(87.5)$ & 0.217 \\
\hline Diuretics & $204(8.8)$ & 0.937 \\
\hline ACEIs or ARBs & $2189(94)$ & 0.324 \\
\hline
\end{tabular}

Continuous variables are presented as median and 25-75 percentiles; nominal variables presented as frequency (\%). Mann-Whitney-U test was used for continuous variables. Pearson-Chi-Square test was used for nominal variables.

Table 2 presents the in-hospital and long-term clinical outcomes of the study population. During hospitalization, patients with higher BUN levels showed significantly higher cardiogenic shock, acute respiratory failure, ventricular arrhythmia, MACE, and mortality rate compared to patients with lower BUN levels. An admission BUN of $17.5 \mathrm{mg} / \mathrm{dL}$ was identified through a ROC analysis as an optimal cutoff value to predict the inhospital mortality with $68 \%$ sensitivity and $66 \%$ specificity (AUC: 0.75; 95\% CI:0.72-0.88; p < 0.001) (Figure 1). Table 3 lists univariate and multivariate hierarchical logistic regression analyses for in-hospital mortality. The univariate predictors of in-hospital mortality were age, male gender, hypertension, diabetes mellitus, previous
CABG, chronic kidney disease, systolic blood pressure, glucose, creatinine, admission CK-MB, white blood cell count, hematocrit, heart rate, left ventricular ejection fraction, heart rate and the BUN value higher than $17.5 \mathrm{mg} / \mathrm{dl}$. By multivariate hierarchical logistic regression analysis, the 5 independent factors that increased the risk of in-hospital mortality were Age [Odds ratio (OR), 1.02; Confidence interval (CI), 1.01 1.04], systolic blood pressure (OR, 0.99; CI, 0.98$0.99)$, glucose (OR, 1.03; CI, $1.01-1.05)$, creatinine (OR, 1.86; CI, 1.48 - 2.39), left ventricular ejection fraction (OR, 0.94; CI, $0.89-$ 0.99 ) and the BUN value higher than $17.5 \mathrm{mg} / \mathrm{dL}$ (OR, 3.42; CI, 2.86 - 4.08).

Table 2. In-hospital and long-term outcomes of patients stratified by admission blood urea nitrogen level.

\begin{tabular}{|c|c|c|c|}
\hline & \multicolumn{2}{|c|}{ Blood Urea Nitrogen Level (mg/dL) } & \multirow[b]{2}{*}{$\begin{array}{c}\mathrm{P} \\
\text { Value } \\
\end{array}$} \\
\hline & $\begin{array}{c}<17.5 \mathrm{mg} / \mathrm{dL} \\
(\mathrm{n}=2328)\end{array}$ & $\begin{array}{l}\geq 17.5 \mathrm{mg} / \mathrm{dL} \\
\quad(\mathrm{n}=1450)\end{array}$ & \\
\hline \multicolumn{4}{|l|}{ In-hospital course } \\
\hline Cardiogenic shock & $74(3.2)$ & $91(6.4)$ & $<0.001$ \\
\hline Acute respiratory failure & $87(3.7)$ & $85(6.0)$ & 0.001 \\
\hline Acute kidney injury & $280(12.0)$ & $165(11.6)$ & 0.708 \\
\hline Ventricular arrhythmia & $125(5.5)$ & $100(7.0)$ & 0.055 \\
\hline $\begin{array}{l}\text { Major adverse cardiac } \\
\text { events }\end{array}$ & $143(6.1)$ & $212(14.9)$ & $<0.001$ \\
\hline Mortality & $53(2.3)$ & $176(12.4)$ & $<0.001$ \\
\hline \multicolumn{4}{|l|}{ Out-hospital course } \\
\hline Follow-up time (month) & $36(36-36)$ & $36(36-36)$ & $<0.001$ \\
\hline $\begin{array}{l}\text { Major adverse cardiac } \\
\text { events }\end{array}$ & $281(12.1)$ & $326(23.0)$ & $<0.001$ \\
\hline All cause mortality & $86(3.7)$ & $263(18.5)$ & $<0.001$ \\
\hline
\end{tabular}

The patients were followed up for a mean period of $33 \pm 0.1$ months. At the out-hospital course, patients with higher BUN levels showed significantly higher MACE and all-cause mortality rate compared to patients with lower BUN levels. The 3-year Kaplan-Meier curve for overall survival in patients with lower and higher
BUN levels were $96.3 \%$ and $81.5 \%$, respectively (Figure 1). Table 4 lists univariate and multivariate Cox regression analyses for 3-year long-term mortality. The univariate predictors of long-term mortality were age, male gender, hypertension, diabetes mellitus, previous CABG, chronic kidney disease, systolic blood pressure, 
glucose, creatinine, admission CK-MB, white blood cell count, hematocrit, heart rate, left ventricular ejection fraction and the BUN value higher than $17.5 \mathrm{mg} / \mathrm{dL}$. By multivariate Cox logistic regression analysis, the 5 independent factors that increased the risk of long-term mortality were age [Hazard ratio (HR), 1.02; Confidence interval (CI), $1.01-1.04]$, systolic blood pressure (HR, 0.99; CI, 0.98-0.99), glucose (HR, 1.02; CI, 1.01 - 1.05), creatinine (HR, 1.79; CI, $1.42-2.26)$ and the BUN value higher than $17.5 \mathrm{mg} / \mathrm{dL}$ (HR, 3.91; CI, $3.04-4.68$ ).

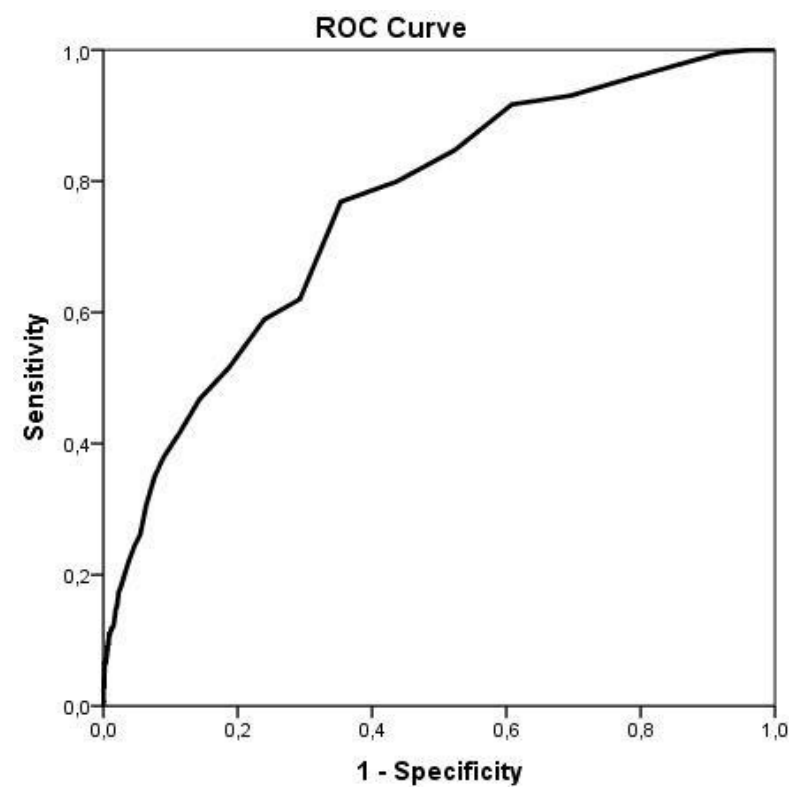

Figure 1. ROC analysis showed that the best cut-off value of the BUN to predict the in-hospital mortality was $17.5 \mathrm{mg} / \mathrm{dL}$ with $68 \%$ sensitivity and $66 \%$ specificity (AUC: $0.75 ; 95 \%$ CI:0.72-0.88; p $<0.001$ ).

As a summary; patients with higher BUN levels had 5.3-times higher in-hospital mortality rates (OR: 6.0, 95\% CI: 4.4-8.3) than patients with lower BUN levels. This significant relationship was persisted even after adjustment for all confounders. Patients with higher BUN levels had
5- $\quad$ times higher long-term mortality rates (HR: 5.3, 95\% CI: 4.2-6.8) than patients with lower BUN levels. This significant relationship was also persisted even after adjustment for all confounders.

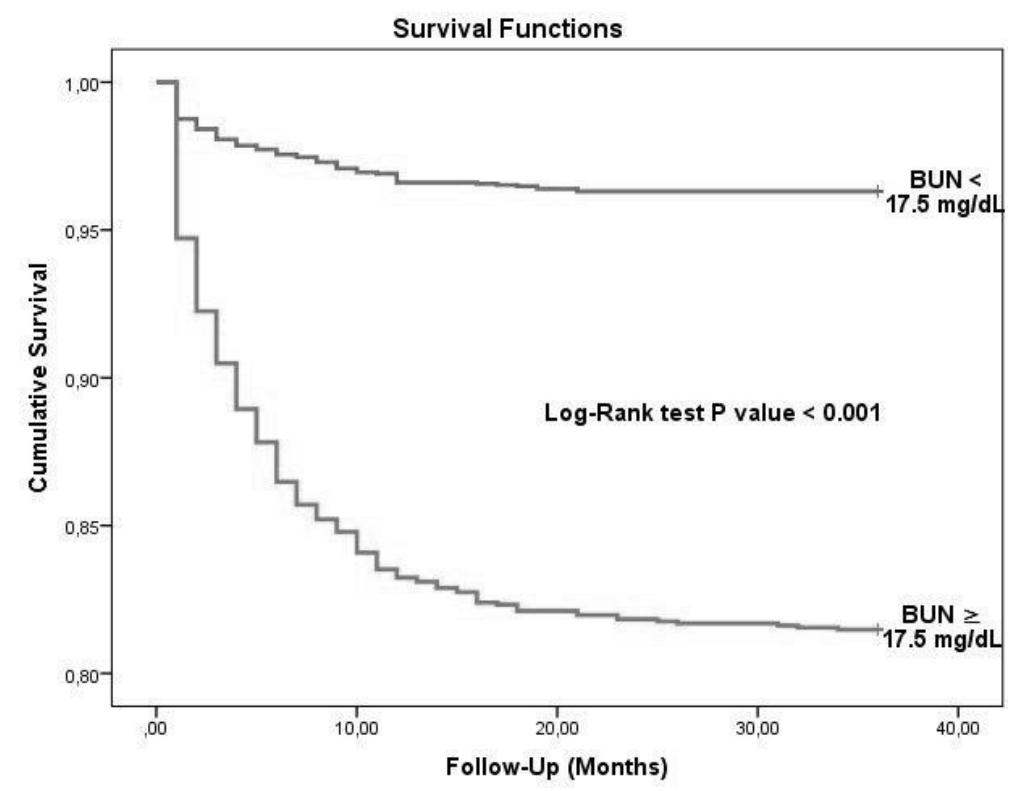

Figure 2. Kaplan-Meier curve for overall survival in patients with ST-segment elevation myocardial infarction (STEMI) $(n=3778)$ stratified by BUN level. 


\section{DISCUSSION}

The mechanisms of acute kidney injury in the setting of cardiac systolic and/or diastolic dysfunction have not been well established due to

the lack of studies. The reduction of cardiac output is not the only reason to explain the reduction in GFR. Ljungman et al. ${ }^{16}$ found that GFR was not reduced until the cardiac index dropped to $<1.6 \mathrm{~L} / \mathrm{min}$. There are several studies suggesting that fluid overload which results in renal venous congestion may be the main mechanism of renal dysfunction in cardiac dysfunction. Nohria et al. ${ }^{17}$, which was supported by another study ${ }^{18}$, demonstrated that only the higher CVP correlated with the lower GFR among all hemodynamic parameters.

In prerenal azotemia, urea increases disproportionately to $\mathrm{sCr}$ on account of enhanced proximal tubular reabsorption that follows the enhanced transport of water and sodium ${ }^{19}$. In distal nephron, urea ${ }_{20}$ reabsorption depends on antidiuretic hormone 20 , which is potentiated by angiotensin $\mathrm{II}^{21}$. Hence, in addition to reflecting

kidney function, BUN levels can reflect a state of hypoperfusion. We hypothesized that BUN might be a good indicator for renal hypoperfusion as a result of cardiac systolic and/or diastolic

dysfunction in the setting of coronary ischemia. Despite the fact that multiple etiologies other than renal hypoperfusion, such as gastrointestinal (GI) bleeding, may explain BUN elevations at baseline; GI bleeding was rare in our study population $(\mathrm{n}=8)$. Hence, hemodynamic factors were most likely to contribute to elevated BUN levels in our study population. Another reason for choosing BUN instead of $\mathrm{sCr}$ was that it remains constant throughout the aging process. Elderly patients may tend to have $\mathrm{sCr}$ levels within normal range despite the fact that their renal function is severely compromised; due to decreased muscle mass ${ }^{22,}{ }^{23}$. In our study, the ROC analysis established that the area under the curve for BUN (AUC: 0.75 ; $95 \%$ CI 0.72 to 0.88 ; $\mathrm{p}<0.001$ ) was higher than that of creatinine (AUC: 0.69 ; $95 \%$ CI 0.65 to $0.74 ; \mathrm{p}<0.001$ ).
The impact of elevated BUN on mortality in the setting of acute decompensated heart failure (ADHF) has been shown in some large-scale studies. Aronson et al. $\quad$ studied 541 patients with a previous diagnosis of heart failure admitted for clinical decompensation. They found that elevated BUN level was a predictor of mortality in patients admitted for ADHF. In a large-scale study also showed that high admission level of BUN was the best single predictor of mortality in patients with ADHF . Thus, the association of BUN levels with mortality in ADHF has been established in a large-scale study.

Some studies have already shown an association between BUN levels and mortality in patients with ACS. Kirtane et al. ${ }^{26}$ studied 9420 patients with ACS, and they found a correlation between increased BUN level and mortality. Their study population consisted of both STEMI (30\%) and non-STEMI $(70 \%)$ patients. Another prospective study included both STEMI and non-STEMI patients showed that increased $\mathrm{BUN}_{27}$ level was associated with in-hospital mortality . However, our study population consisted of only patients with STEMI treated with pPCI. This difference limits the direct $_{28}$ comparison of two studies. Aronson et al. studied 1507 patients with STEMI treated with thrombolytic therapy or pPCI, and they showed the relationship between elevated BUN levels and long-term mortality. In spite of the fact that the study population was not homogeneous in terms of treatment, they included only STEMI patients and our study supports their findings indicating that elevated BUN level predicts long-term of mortality. Our study showed that an increase in BUN levels was independently associated with a high risk of in-hospital and longterm all-cause mortality, and MACE (Table 3). Patients with higher BUN levels on admission had 5.3-times higher in-hospital and 5-times higher long-term mortality rates, which had higher sensitivity and specificity over $\mathrm{sCr}$ levels. 
Table 3. Univariate predictors and multivariate hierarchical logistic regression analysis for in-hospital mortality. All clinically relevant parameters were included in the model.

\begin{tabular}{|c|c|c|c|c|}
\hline Univariate Analysis & P value & Multivariate Model & P value & OR (95\% CI) \\
\hline Age & $<0.001$ & Age & $<0.001$ & $1.02(1.01-1.04)$ \\
\hline Male gender & 0.001 & & & \\
\hline Hypertension & 0.051 & & & \\
\hline Diabetes Mellitus & 0.001 & & & \\
\hline Previous CABG & 0.016 & & & \\
\hline Chronic kidney disease & $<0.001$ & & 0.006 & $0.99(0.98-0.99)$ \\
\hline Systolic blood pressure & $<0.001$ & $\begin{array}{c}\text { Systolic blood } \\
\text { pressure }\end{array}$ & & \\
\hline Glucose & $<0.001$ & Glucose & $<0.001$ & $1.03(1.01-1.05)$ \\
\hline Creatinine & $<0.001$ & Creatinine & $<0.001$ & $1.86(1.48-2.39)$ \\
\hline Admission CK-MB & $<0.001$ & & & \\
\hline White blood cell count & 0.003 & & & \\
\hline Hematocrit & 0.006 & & & \\
\hline Heart rate & 0.059 & & & \\
\hline LVEF & $<0.001$ & LVEF & 0.004 & $0.94(0.89-0.99)$ \\
\hline BUN $\geq 17.5$ mg/dL & $<0.0010$ & BUN $\geq 17.5 \mathrm{mg} / \mathrm{dL}$ & $<0.001$ & $3.42(2.86-4.08)$ \\
\hline
\end{tabular}

Only parameters that reached statistical significance at univariate analysis were given in the rightmost column. OR, Odds ratio; CI, confidence interval; CABG; Coronary artery bypass graft surgery; CK-MB, creatine kinase-myocardial band; LVEF, left ventricular ejection fraction; BUN, blood urea nitrogen.

Table 4. Univariate predictors and multivariate Cox proportional analysis of 3-year mortality. All clinically relevant parameters were included in the model.

\begin{tabular}{|c|c|c|c|c|}
\hline Univariate Analysis & P value & Multivariate Model & $P$ value & HR $(95 \%$ CI) \\
\hline Age & $<0.001$ & Age & $<0.001$ & $1.02(1.01-1.04)$ \\
\hline Male gender & $<0.001$ & & & \\
\hline Hypertension & $<0.001$ & & & \\
\hline Diabetes Mellitus & 0.002 & & & \\
\hline Previous CABG & 0.005 & & & \\
\hline Chronic kidney disease & $<0.001$ & & & \\
\hline Systolic blood pressure & $<0.001$ & $\begin{array}{l}\text { Systolic blood } \\
\text { pressure }\end{array}$ & 0.006 & $0.99(0.98-0.99)$ \\
\hline Glucose & $<0.001$ & Glucose & $<0.001$ & $1.02(1.01-1.05)$ \\
\hline Creatinine & $<0.001$ & Creatinine & $<0.001$ & $1.79(1.42-2.26)$ \\
\hline Admission CK-MB & $<0.001$ & & & \\
\hline White blood cell count & 0.001 & & & \\
\hline Hematocrit & 0.021 & & & \\
\hline Heart rate & 0.078 & & & \\
\hline LVEF & $<0.001$ & & & \\
\hline $\mathrm{BUN} \geq 17.5 \mathrm{mg} / \mathrm{dL}$ & $<0.001$ & $\mathrm{BUN} \geq 17.5 \mathrm{mg} / \mathrm{dL}$ & $<0.001$ & $3.91(3.04-4.68)$ \\
\hline
\end{tabular}

Only parameters that reached statistical significance at univariate analysis were given in the leftmost column. OR, Odds ratio; $\mathrm{CI}$, confidence interval; CABG; Coronary artery bypass graft surgery; CK-MB, creatine kinase-myocardial band; LVEF, left ventricular ejection fraction; BUN, blood urea nitrogen. 


\section{Limitations}

There are some limitations of our study. A total of 66 patients were excluded from the study due to inaccurate recording of the laboratory results and historical data. Thus, neither in-hospital nor longterm mortality was assessed for those patients. Our population was limited to patients with STEMI undergoing pPCI. Hence our results should not be generalized to all patients with ACS. There were significant differences in terms of gender and age between two groups. It might affect the findings of the study. The study was carried out in a single tertiary referral heart center. On account of the fact that high-risk patients are referred for pPCI to our heart center, it may have affected our results. So, there was a possibility of selection bias although great attention was paid to include all consecutive STEMI patients managed with pPCI to avoid selection bias. Another limitation of the study originates from the nature of retrospective design. We were not able to reach all baseline characteristics and follow-up parameters, which can affect the eGFR of the patients such as body mass index, medications, and the daily urine output.

\section{CONCLUSION}

In conclusion, this study demonstrated that elevated BUN level was independently associated with increased in-hospital and long-term mortality, and MACE. BUN test is a simple, inexpensive, and easily bedside applicable method. Hence, it can be used to detect high-risk patients in the setting of STEMI.

\section{REFERENCES}

1. Mozaffarian D, Benjamin EJ, Go AS, Arnett DK, Blaha MJ, Cushman M, Das SR, de Ferranti S, Després JP, Fullerton HJ, Howard VJ, Huffman MD, Isasi CR, Jiménez MC, Judd SE, et al. Heart Disease and Stroke Statistics-2016 Update: A Report From the American Heart Association. Circulation 2016;133:38-360.

2. Lee KL, Woodlief LH, Topol EJ, Weaver WD, Betriu A, Col J, Simoons M, Aylward P, Van de Werf F, Califf RM. Predictors of 30-day mortality in the era of reperfusion for acute myocardial infarction. Results from an international trial of 41,021 patients. GUSTO-I
Investigators. Circulation 1995;91:1659_ 1968.

3. Antman EM, Tanasijevic MJ, Thompson B, Schactman M, McCabe $\mathrm{CH}$, Cannon CP, Fischer GA, Fung AY, Thompson C, Wybenga D, Braunwald E. Cardiacspecific troponin I levels to predict the risk of mortality in patients with acute coronary syndromes. $N$ Engl $J$ Med 1996;335:1342-1349.

4. de Lemos JA, Morrow DA, Bentley JH, Omland T, Sabatine MS, McCabe $\mathrm{CH}$, Hall C, Cannon CP, Braunwald E. The prognostic value of $\mathrm{B}$-type natriuretic peptide in patients with acute coronary syndromes. $N$ Engl $J$ Med 2001;345:1014-1021.

5. Capes SE, Hunt D, Malmberg K, Gerstein HC. Stress hyperglycemia and increased risk of death after myocardial infarction in patients with and without diabetes: a systematic overview. Lancet 2000;355:773-778.

6. Kosiborod M, Rathore SS, Inzucchi SE, Masoudi FA, Wang Y, Havranek EP, Krumholz HM. Admission glucose and mortality in elderly patients hospitalized with acute myocardial infarction: implications for patients with and without recognized diabetes. Circulation 2005;111:3078-3086.

7. Al Suwaidi J, Reddan DN, Williams K, Pieper KS, Harrington RA, Califf RM, Granger CB, Ohman EM, Holmes DR Jr. Prognostic implications of abnormalities in renal function in patients with acute coronary syndromes. Circulation 2002;106:974-980.

8. Sarnak MJ, Levey AS, Schoolwerth AC, Coresh J, Culleton B, Hamm LL, McCullough PA, Kasiske BL, Kelepouris E, Klag MJ, Parfrey P, Pfeffer M, Raij L, Spinosa DJ, Wilson PW. Kidney disease as a risk factor for development of cardiovascular disease: a statement from the American heart association councils on kidney in cardiovascular disease, high blood pressure research, clinical cardiology, and epidemiology and prevention. Circulation 2003;108(17):2154-2169.

9. Anavekar NS, McMurray JJ, Velazquez EJ, Solomon SD, Kober L, Rouleau JL, White HD, Nordlander R, Maggioni A, Dickstein K, Zelenkofske S, Leimberger JD, Califf RM, Pfeffer MA. Relation between renal dysfunction and 
cardiovascular outcomes after myocardial outcomes after myocardial infarction. $N$ Eng J Med 2004;351(13):1285-1295.

10. Santopinto JJ, Fox KA, Goldberg RJ, Budaj A, Piñero G, Avezum A, Gulba D, Esteban J, Gore JM, Johnson J, Gurfinkel EP; GRACE Investigators. Creatinine clearance and adverse hospital outcomes in patients with acute coronary syndromes: finding from the global registry of acute coronary events (GRACE). Heart 2003;89(9):1003-1008.

11. Eagle KA, Lim MJ, Dabbous OH, Pieper KS, Goldberg RG, Van de Werf F, Goodman SG, Granger CB, Steg PG, Gore JM, Budaj A, Avezum A, Flather MD, Fox KA; GRACE investigators. A validated prediction model for all forms of acute coronary syndrome: estimating the risk of 6-month post discharge death in an international registry. JAMA 2004;291(22):2727-2733.

12. Schiller NB, Shah PM, Crawford M, DeMaria A, Devereux R, Feigenbaum H, Gutgesell H, Reichek N, Sahn D, Schnittger I. Recommendations for quantitation of the left ventricle by twodimensional echocardiography. American Society of Echocardiography Committee on Standards, Subcommittee on Quantitation of Two-Dimensional Echocardiograms. J Am Soc Echocardiogr 1989;2:358-367.

13. Cockcroft D. Prediction of creatinine clearance from serum creatinine. Nephron 1976;16:31-41.

14. Task force on the management of STsegment elevation acute myocardial infarction of European Society of Cardiology (ESC), Steg PG, James SK, Atar D, Badano LP, BlömstromLundqvist C, Borger MA, Di Mario C, Dickstein K, Ducrocq G, FernandezAviles F, Gershlick AH, Giannuzzi P, Halvorsen S, Huber K, Juni P, et al. ESC Guidelines for the management of acute myocardial infarction in patients presenting with ST-segment elevation. Eur Heart J 2012;33:2569-2619.

15. Ad-hoc working group of ERBP, Fliser D, Laville M, Covic A, Fouque D, Vanholder R, Juillard L, Van Biesen W. A European Renal Best Practice (ERBP) position statement on the Kidney Disease Improving Global Outcomes (KDIGO) clinical practice guidelines on acute kidney injury: part 1: definitions, conservative management and contrastinduced nephropathy. Nephrol Dial Transplant 2012;27(12):4263-4272.

16. Ljungman S, Laragh JH, Cody RJ. Role of the kidney in congestive heart failure relationship of cardiac index to kidney function. Drugs 1990;39 (Suppl 4):10-21.

17. Nohria A, Hasselblad V, Stebbins A, Pauly DF, Fonarow GC, et al. Cardiorenal interactions: insights from the ESCAPE trial. J Am Coll Cardiol 2008;51:12681274.

18. Mullens W, Abrahams Z, Francis GS, Sokos G, Taylor DO, et al. Importance of venous congestion for worsening of renal function in advanced decompensated heart failure. $J \mathrm{Am}$ Coll Cardiol 2009;53:589-596.

19. Lin J, Denker BM. Azotemia and urinary abnormalities. In: Longo DL, Fauci AS, Kasper DL, Hauser SL, Jameson SL, Loscalzo J, editors. $18^{\text {th }}$ Harrison's principles of internal medicine. McGrawHill Education; 2012. pp.334-341.

20. Conte G, Dal Canton A, Terrible M, Cianciaruso B, Di Minno G, Pannain M, Russo D, Andreucci VE. Renal handling of urea in subjects with persistent azotemia and normal renal function. Kidney Int 1987;32(5):721-727.

21. Kingler C, Ancellin N, Barrault MB, Morel A, Buhler JM, Elalouf JM, Clauser E, Lugnier C, Corman B. Angiotensin II potentiates vasopressin-dependent cAMP accumulation in $\mathrm{CHO}$ transfected cells. Mechanism of cross-talk between AT1A and V2 receptors. Cell Signal 1998;10(1):65-74.

22. Duncan L, Heathcote J, Djurdjev O, Levin A. Screening for renal disease using serum creatinine: who are we missing? Nephrol Dial Transplant 2001;16(5):1042-1046.

23. Swedko PJ, Clark HD, Paramsothy K, Akbari A. Serum creatinine is an inadequate screening test for renal failure in elderly patients. Arch Intern Med 2003;163(3):356-360.

24. Aronson D, Mittleman MA, Burger AJ. Elevated blood urea nitrogen level as a predictor of mortality in patients admitted for decompensated heart failure. $\mathrm{Am} J$ Med 2004;116:466-473.

25. Fonarow GC, Adams Jr KF, Abraham WT, Yancy CW, Boscardin WJ. Risk stratification for in-hospital mortality in acutely decompensated heart failure: 
classification and regression tree analysis. JAMA 2005;293:572-580.

26. Kirtane AJ, Leder DM, Waikar SS, Chertow GM, Ray KK, Pinto DS, Karmpaliotis D, Burger AJ, Murphy SA, Cannon CP, Braunwald E, Gibson CM; TIMI Study Group. Serum blood urea nitrogen as an independent marker of subsequent mortality among patients with acute coronary syndromes and normal to mildly reduced glomerular filtration rates. J Am Coll Cardiol 2005;45:1781-1786.

27. Saygitov RT, Glezer MG, Semakina SV. Blood urea nitrogen and creatinine levels at admission for mortality risk assessment in patients with acute coronary syndromes. Emerg Med J 2010;27(2):105109.

28. Aronson D, Hammerman H, Beyar R, Yalonetsky S, Kapeliovich M, Markiewicz W, Goldberg A. Serum blood urea nitrogen and long-term mortality in acute ST-elevation myocardial infarction. Int J Cardiol 2008;127(3):380-385. 